\title{
Optimalisasi Pemahaman Konsep Belajar IPA Siswa Sekolah Dasar melalui Model Pembelajaran Inkuiri dengan Metode Gallery Walk (Sebuah Studi Literatur)
}

\author{
Putri Mayang Sari ${ }^{1}$, Sumarli ${ }^{2}$ \\ STKIP Singkawang, Singkawang, Indonesia \\ pmy.sari@gmail.com ${ }^{1}$, sumarliphysics@gmail.com ${ }^{2}$
}

\section{Kata Kunci :}

Model Pembelajaran Inkuiri, Gallery Walk, Pemahaman

Konsep, IPA

\begin{abstract}
ABSTRAK
Model pembelajaran inkuiri adalah suatu rangkaian kegiatan belajar yang melibatkan seluruh kemampuan siswa untuk mencari dan menyelidiki secara sistematis, kritis, logis, analitis sehingga dapat merumuskan sendiri penemuannya dengan percaya diri. Saat merumuskan penemuannya diperlukan pemahaman konsep belajar yang dapat dimunculkan melalui metode pembelajaran gallery walk. Studi ini bertujuan untuk mengoptimalisasi pemahaman konsep belajar Ilmu Pengetahuan Alam (IPA) siswa Sekolah Dasar (SD) melalui model pembelajaran inkuiri dengan metode gallery walk. Metode penelitian yang digunakan adalah studi literatur. Hasil penelaahan menunjukkan bahwa model pembelajaran inkuiri dengan metode gallery walk dapat membantu mengoptimalkan pemahaman konsep belajar IPA Siswa SD.
\end{abstract}

\section{PENDAHULUAN}

Ilmu Pengetahuan Alam merupakan salah satu mata pelajaran yang harus dipelajari oleh siswa. Ruang lingkup Ilmu Pengetahuan Alam berhubungan dengan kehidupan sehari-hari dan yang ada di lingkungan sekitar, mulai dari fenomena alam sampai gejala terbentuknya suatu benda. Berdasarkan kurikulum tingkat satuan pendidikan ruang lingkup bahan kajian IPA untuk SD/MI meliputi aspekaspek: (1) Makhluk hidup dan proses kehidupan meliputi manusia, hewan, dan tumbuhan dan interaksinya dengan lingkungan serta kesehatan, (2) Benda/materi, sifat-sifat dan kegunaannya meliputi cair, padat, dan gas, (3) Energi dan perubahannya meliputi gaya, bunyi, panas, magnet, listrik, cahaya, dan pesawat sederhana, (4) Bumi dan alam semesta meliputi tanah, bumi, tata surya, dan benda-benda langit lainnya.

Pembelajaran Ilmu Pengetahuan Alam membutuhkan penelitian dan penalaran dari siswa. Karena di dalam mata pelajaran itu mencakup tiga pertanyaan mendasar yang memerlukan jawaban yaitu apa yang terjadi, bagaimana itu terjadi, dan mengapa itu terjadi. Oleh karena itu di perlukan untuk melakukan penalaran dan penelitian. Sebelum melakukan penalaran dan penelitian siswa terlebih dahulu harus memahami konsep belajar yang terkandung di dalam ruang lingkup bahan kajian IPA yang di ajarkan oleh guru. 
Konsep belajar merupakan kegiatan yang menggunakan unsur fundamental pada setiap jenis dan jenjang pendidikan nya. Konsep belajar adalah hal yang paling dasar dan paling pertama di ajarkan oleh guru. Konsep belajar menjadi penentu hasil akhir dari proses pembelajaran. Tingkat keberhasilan siswa dalam menguasai pembelajaran tergantung pada sejauh mana siswa menguasi konsep belajar tersebut. Selain itu keterampilan guru dalam menerapkan konsep belajar pada proses pembelajaran juga berpengaruh terhadap pemahaman konsep belajar siswa. guru harus menguasai, memahami, dan menerapkan konsep belajar dengan baik sehingga dapat tercapainya tujuan pembelajaran dan siswa dapat mengikuti pembelajaran secara efektif.

Kemampuan pemahaman konsep adalah kemampuan siswa yang berupa penguasaan materi pelajaran dimana siswa tidak hanya menghafal atau mengingat suatu konsep yang dipelajari tetapi mampu menyatakan ulang konsep tersebut dalam bentuk lain yang mudah dimengerti (Sagala, 2009). Kemampuan pemahaman konsep ini merupakan bagian terpenting dalam pembelajaran IPA sebab dengan menguasai konsep materi dasar atau prasyarat akan memudahkan siswa dalam memahami dan memecahakan masalah dalam pembelajaran IPA. Pada kenyataannya tingkat pemahaman konsep belajar IPA siswa SD masih rendah dan kurang optimal. Satu diantara faktor yang mempengaruhi hal tersebut adalah proses pembelajaran yang hanya berpusat pada guru. Pembelajaran yang hanya berpusat pada guru menyebabkan siswa kurang tertarik mengikuti proses pembelajaran yang berlangsung dimana guru hanya aktif menjelaskan materi dan informasi yang ada kemudian mengerjakan dan menjelaskan beberapa contoh soal yang ada di buku. Siswa diberi kesempatan untuk mencatat, mendengarkan, dan mengerjakan soal sesuai dengan contoh soal yang diberikan oleh guru saja. Guru tidak memperhatikan keaktifan, pemahaman, dan ketertarikan siswa pada proses pembelajaran yang sedang berlangsung (Sumarli, 2018). Akibatnya siswa menjadi kurang aktif dan sebagian besar siswa akan mengalami kesulitan dalam memahami konsep materi.

Berdasarkan hal tersebut, guru dituntut untuk senantiasa melakukan inovasi dalam pembelajaran pada berbagai aspeknya, mulai dari visi, misi, tujuan, program, layanan, metode, teknologi, proses, sampai evaluasi. Bagi seorang guru, pemilihan model pembelajaran hendaknya dilakukan secara cermat agar pilihan itu tepat atau relevan dengan berbagai aspek pembelajaran yang lain, efisien dan menarik. Oleh karena itu, perlu dikembangkan sebuah model pembelajaran untuk mengoptimalkan pemahaman konsep belajar siswa dengan membangkitkan semangat siswa agar aktif dalam proses pembelajaran. Model pembelajaran inkuiri merupakan salah satu solusi untuk mengatasi masalah dalam pemahaman konsep belajar siswa, dimana pada model pembelajaran inkuiri merupakan suatu pembelajaran yang berpusat pada siswa dimana kelompok-kelompok siswa memperoleh informasi atau mencari jawaban melalui observasi atau eksperimen dengan menggunakan kemampuan berpikir logis dan kritis. Adanya eksperimen dalam pembelajaran dapat memberikan pengalaman tersendiri bagi siswa dalam memahami fenomena alam sekitar (Sumarli, Murdani, \& Wijaya, 2017). Oleh karena itu, penerapan model pembelajaran inkuri membantu siswa agar lebih mudah memahami konsep yang dipelajari. Pelaksanaan model pembelajaran inkuiri dapat didukung dengan menerapakan metode pembelajaran gallery walk.

Metode Pembelajaran gallery walk dapat mengembangkan pemahaman konsep belajar siswa. Hal ini karena metode pembelajaran ini memberikan kesempatan bagi siswa bekerja sama antar siswa kelompok kecil untuk menyampaikan materi yang ada ke kelompok lain sehingga siswa aktif bertanya, mempertanyakan, dan mengemukakan. Siswa akan berdiskusi, saling mengoreksi pemahaman dan berpresentasi, sehingga siswa akan terlibat aktif dalam aktivitas-aktivitas belajar dikelas. Selain itu, setiap kelompok melakukan presentasi, guru mengklarifikasi,dan bersama-sama menyimpulkan agar tidak terjadi kesalahan dalam memahami konsep yang diperoleh. Berdasarkan paparan tersebut, dilakukan sebuah studi literatur tentang optimalisasi pemahaman konsep belajar IPA siswa SD melalui model pembelajaran inkuiri dengan metode gallery walk. Buyung, B., \& Dwijanto, D. (2017) menurut Keunggulan menggunakan model pembelajaran inkuiri ini dapat mengatasi pembelajaran yang cenderung pasif. 


\section{METODE}

Studi ini menggunakan studi literatur atau literature review dengan menganalisis beberapa kajian yang berkaitan dengan topik pembahasan yaitu model pembelajaran inkuiri, metode pembelajaran gallery walk, dan konsep belajar IPA. Sumber-sumber rujukan yang menjadi pokok bahasan bersumber dari buku, jurnal, dan yang lainnya. Hal tersebut dimaksudkan untuk meninjau penerapan model pembelajaran inkuiri dipadukan dengan metode pembelajaran gallery walk sebagai sarana untuk mengoptimalkan pemahaman konsep belajar IPA siswa SD.

\section{HASIL DAN PEMBAHASAN}

\section{Model Pembelajaran Inkuiri}

Penggunaan model pembelajaran dalam kegiatan pembelajaran sangat diperlukan karena untuk mempermudah proses pembelajaran sehingga dapat diperoleh hasil yang optimal pada materi pelajaran yang diberikan. Terlebih pada proses pemahaman konsep yang menjadi hal paling dasar dan paling utama yang harus dipahami oleh siswa pada proses pembelajaran. Penerapan model pembelajaran yang tepat dapat mengoptimalkan proses pemahaman konsep belajar siswa khusus nya pada mata pelajaran IPA yang mana setiap materi pembelajaran IPA berisi sejumlah konsep yang harus dikuasai oleh siswa. Konsep-konsep tersebut biasanya tersusun secara logis, terstruktur, dan sistematis serta dimulai dari konsep-konsep yang sederhana hingga konsep-konsep yang kompleks

Model pembelajaran inkuiri dapat digunakan dalam proses pengoptimalan pemahaman konsep belajar siswa. Model pembelajaran inkuiri adalah model pembelajaran yang menekankan kepada siswa untuk lebih aktif dalam pembelajaran, dimana siswa dapat menemukan atau meneliti masalah berdasarkan fakta untuk memperoleh data. Inkuiri menurut Komalasari (2011: 73) merupakan model pembelajaran yang berupaya menanamkan dasar-dasar berpikir ilmiah pada diri siswa, sehingga dalam proses pembelajaran ini siswa lebih banyak belajar sendiri, mengembangkan kreativitas dalam memahami konsep dan memecahkan masalah. Model inkuiri merupakan model yang mempersiapkan siswa pada situasi untuk melakukan eksperimen sendiri secara luas agar melihat apa yang terjadi, ingin melakukan sesuatu, mengajukan pertanyaan-pertanyaan, dan mencari jawabannya sendiri, serta menghubungkan penemuan yang satu dengan penemuan yang lain, membandingkan apa yang ditemukannya dengan yang ditemukan siswa lain. Strategi pembelajaran inquiry merupakan bentuk dari pendekatan pembelajaran yang berorientasi kepada siswa (student centered approach). Dikatakan demikian karena dalam strategi ini siswa memegang peran yang sangat dominan dalam proses pembelajaran (Sanjaya, 2011). Model pembelajaran inkuiri memberi ruang kepada siswa untuk belajar sesuai dengan gaya belajar mereka sendiri sehingga memudahkan siswa dalam memahami konsep belajar dalam suatu pembelajaran. Proses model pembelajaran inkuiri ini bermula dari satu perhatian dan minat atas sesuatu yang menarik dan seterusnya akan muncul banyak pertanyaan atas minat tersebut. Fenomena yang diperhatikan biasanya tidak mempunyai kaitan dengan pengalaman maupun pemahaman dari para siswa. Sifat ingin tahu seterusnya merangsang tindakan untuk melakukan penelitian, pertanyaan, ramalan, hipotesa, dan konsep awal (Indah, 2012). Keunggulan menggunakan SPI, yaitu siswa tidak hanya melakukan pembelajaran melalui proses penghafalan tanpa berpikir melainkan siswa dituntut untuk aktif dan kreatif pada kegiatan pembelajaran (Buyung, B., Nirawati, R., \& Kusumawati, I. (2016)).

Langkah-langkah pembelajaran model inkuiri dalam penelitian ini yaitu, meliputi: merumuskan masalah, mengamati atau melakukan observasi lapangan, menganalisis dan menyajikan hasil dalam tulisan, gambar, laporan, bagan, tabel, dan karya lainnya, serta mengkomunikasikan atau menyajikan hasil karya pada pembaca, teman sekelas, guru atau audien lainnya. Dengan demikian model pembelajaran inkuiri mampu menciptakan siswa yang cerdas dan berwawasan. Dengan model ini siswa dilatih untuk selalu berpikir kritis karena membiasakan siswa memecahkan suatu masalah 
sendiri.

\section{Metode Pembelajaran Gallery Walk}

Penggunaan metode dalam kegiatan pembelajaran sangat diperlukan karena untuk mempermudah proses pembelajaran sehingga dapat diperoleh hasil yang optimal pada materi pelajaran yang diberikan. Metode gallery walk merupakan salah satu dari model pembelajaran Active Learning. Model pembelajaran Active Learning merupakan suatu bentuk proses pembelajaran yang lebih menekankan siswa untuk bergerak aktif sebagai subyek belajar yakni siswa mendengar, melihat, mengajukan pertanyaan, dan mendiskusikan tentang satu materi pembelajaran (Desi, 2010). Gallery walk terdiri dari dua kata yaitu gallery dan walk. Gallery artinya pameran. Sedangkan, walk artinya berjalan, melangkah. Jadi, gallery walk adalah kegiatan untuk memperkenalkan produk atau hasil karya seni para siswa, kemudian dinilai oleh siswa yang lain. Sehingga siswa dapat melakukan refleksi ketika umpan balik datang dari teman sekelas (Laura dkk., 2014). Pendapat di atas sejalan dengan Vygotsky berpendapat bahwa siswa membentuk pengetahuan sebagai hasil dari pikiran maupun kegiatan siswa sendiri. Teori Vygotsky ini lebih menekankan pada aspek sosial dari pembelajaran, menurutnya proses pembelajaran akan terjadi jika pemberian bantuan kepada anak selama tahap awal perkembangan serta memberikan kesempatan kepada anak untuk mengambil alih tanggung jawab. Teori ini juga meyakini bahwa perkembangan intelektual terjadi pada saat individu berhadapan dengan pengalaman baru dan menantang, dan ketika mereka berusaha (Trianto, 2009). Galeri dalam Kamus Besar Bahasa Indonesia diartikan ruangan yang digunakan untuk memamerkan karya seni. Galeri merupakan suatu cara untuk menilai dan mengingat apa yang telah dipelajari siswa selama berlangsungnya pembelajaran (Silberman, 2006). Gallery walk merupakan model pembelajaran kelompok yang masing-masing anggota mendapat kesempatan untuk memberikan kontribusi mereka dan mendengarkan pandangan serta pemikiran anggota lainnya (Dengo, 2018). Menurut Wirdati dkk. (2013), metode pembelajaran gallery walk juga dapat memotivasi keaktifan siswa dalam proses belajar sebab bila sesuatu yang baru ditemukan berbeda antara satu dengan yang lainnya maka dapat saling mengkoreksi antara sesama siswa baik kelompok maupun antar siswa itu sendiri. Strategi pembelajaran pada metode gallery walk mengambil psikologi kognitif sebagai dukungan teoritisnya. Fokusnya bukan apa yang sedang dikerjakan siswa tetapi pada apa yang mereka pikirkan. Pada kegiatan ini, guru lebih berperan sebagai pembimbing dan fasilitator siswa untuk berpikir dan menggali informasi baru untuk menyelesaikan suatu permasalahan.

Metode gallery walk merupakan suatu cara untuk menilai dan mengingat apa yang dipelajari siswa selama ini. Prosedur dalam metode gallery walk, yaitu: (1) Bagilah siswa menjadi beberapa kelompok yang beranggotakan dua hingga empat orang. (2) Perintahkan tiap kelompok untuk mendiskusikan apa yang didapatkan oleh anggotanya dari pelajaran yang siswa ikuti. Kemudian perintahkan mereka untuk membuat sebuah daftar pada kertas lebar hasil pembelajaran ini. (3) Tempelkan daftar tersebut pada dinding. (4) Perintahkan siswa untuk berjalan melewati tiap daftar, perintahkan agar tiap siswa untuk memberikan tanda centang di dekat hasil belajar yang juga ia dapatkan pada daftar selain daftarnya sendiri. (5) Surveilah hasilnya, cermati hasil pembelajaran yang paling umum didapatkan. Jelaskan sebagian hasil pembelajaran yang tidak biasa (Silberman, 2006). Prosedur metode gallery walk memberikan kesempatan kepada siswa mengembangkan kemampuan dengan mengamati segala peragaan/benda yang sedang terlibat dalam proses serta dapat mengambil kesimpulan-kesimpulan yang sesuai. Prosedur atau langkah-langkah metode gallery walk yang dikemukakan diatas, bukanlah bersifat mutlak melainkan dapat diberikan variasi sesuai dengan tujuan belajar yang akan dilaksanakan.

Metode gallery walk tersebut dapat menghemat waktu pelajaran karena siswa langsung praktik tanpa guru harus berbicara panjang lebar dan mereka juga akan lebih mudah memahami pelajaran. Penggunaan strategi ini juga dapat memberikan kesempatan kepada siswa untuk membuat suatu karya dan melihat hasil karya kelompok lain sehingga mereka dapat saling melihat dan memperbaiki kekurangan satu sama lain. Selain itu metode pembelajaran gallery walk juga menangani berbagai keterampilan kognitif meliputi analisis, evaluasi dan sintesis (Sanjaya, 2012). 
Dengan demikian metode gallery walk merupakan suatu metode pembelajaran yang mampu menimbulkan daya emosional siswa untuk menemukan pengetahuan baru dan dapat mempermudah daya ingat jika sesuatu yang ditemukan itu dilihat secara langsung. Gallery walk juga dapat memotivasi keaktifan siswa dalam proses belajar sebab bila sesuatu yang baru ditemukan berbeda antara satu dengan yang lainnya maka dapat saling mengkoreksi antara sesama siswa baik kelompok maupun antar siswa itu sendiri (Mariam, 2017). Kondisi ini dapat membuat belajar siswa menjadi lebih menyenangkan, sehingga tujuan pembelajaran yang diharapkan dapat tercapai.

\section{Pemahaman Konsep Belajar IPA}

Menurut Purwanto (2008: 44), pemahaman adalah tingkat kemampuan yang mengharapkan siswa mampu memahami konsep, situasi, dan fakta yang diketahuinya. Hal itu sejalan dengan Uno dan Mohamad (2014: 57) yang menyatakan bahwa pemahaman diartikan sebagai kemampuan seseorang dalam mengartikan, menafsirkan, menerjemahkan atau menyatakan sesuatu dengan caranya sendiri tentang pengetahuan yang pernah diterimanya. Dengan demikian, dari beberapa pendapat datas dapat disimpulkan bahwa pemahaman merupakan kemampuan seseorang untuk menyatakan kembali pengetahuan atau fakta-fakta yang pernah diterima dengan menggunakan bahasanya sendiri.

Menurut Samatowa (2016: 52), konsep merupakan abstraksi yang berdasarkan pengalaman. Konsep merupakan kesimpulan dari suatu pengertian yang terdiri dari dua atau lebih fakta dengan memiliki ciri-ciri yang sama (Tjandra dkk., 2005). Letak sebuah konsep dalam pembelajaran IPA merupakan bagian dari produk yang meliputi fakta-fakta IPA. Hal itu sejalan dengan Susanto (2016: 168) menjelaskan bahwa konsep IPA merupakan suatu ide yang mempersatukan fakta-fakta IPA. Depdiknas (2003: 24) menjelaskan bahwa pemahaman konsep merupakan salah satu kecakapan atau kemahiran yang diharapkan dapat tercapai dalam belajar IPA yaitu dengan menunjukkan pemahaman konsep IPA yang dipelajarinya, menjelaskan keterkaitan antarkonsep dan mengaplikasikan konsep secara akurat, efisien, dan tepat dalam pemecahan masalah. Berdasarkan paparan tersebut, dapat disimpulkan bahwa pemahaman konsep IPA merupakan kemampuan siswa untuk dapat memahami suatu konsep atau fakta dan menjawabnya dengan menggunakan kalimat sendiri tanpa mengubah arti dari konsep yang dimaksudkan. Pemahaman konsep IPA diartikan merupakan proses pemaparan suatu fakta atau konsep IPA secara rinci, melalui pengamatan dan percobaan.

Anderson dan Krathwohl (2010: 106) mengemukakan bahwa kategori memahami mencakup tujuh proses kognitif, meliputi: menafsirkan (interpreting), memberikan contoh (exemplifying), mengklasifikasikan (classifying), meringkas (summarizing), menarik inferensi/menyimpulkan (inferring), membandingkan (comparing), dan menjelaskan (explaining). (1) Menafsirkan (interpreting), yaitu mengubah dari suatu bentuk informasi ke bentuk informasi lainnya, misalnya dari kata-kata ke grafik atau gambar, atau sebaliknya, dari kata-kata ke angka, atau sebaliknya, maupun dari kata-kata ke kata-kata, misalnya meringkas atau membuat paraphrase; (2) Memberikan contoh (exemplifying), yaitu memberikan contoh dari suatu konsep atau prinsip yang bersifat umum. Memberikan contoh menuntut kemampuan mengidentifikasi ciri khas suatu konsep dan selanjutnya menggunakan ciri tersebut untuk membuat contoh; (3) Mengklasifikasikan (classifying), yaitu mengenali bahwa sesuatu (benda atau fenomena) masuk dalam kategori tertentu; (4) Meringkas (summarizing), yaitu membuat suatu pernyataan yang mewakili seluruh informasi atau membuat suatu abstrak dari sebuah tulisan; (5) Menarik inferensi (inferring), yaitu menemukan suatu pola dari sederetan contoh atau fakta; (6) Membandingkan (comparing), yaitu mendeteksi persamaan dan perbedaan yang dimiliki dua objek, ide ataupun situasi; dan (7) Menjelaskan (explaining), yaitu mengkonstruk dan menggunakan model sebab-akibat dalam suatu sistem.

Menurut Purwanto (2008: 44), tingkat siswa dikatakan memahami suatu konsep adalah sebagai berikut: (1) Pemahaman terjemahan, seperti dapat menjelaskan arti suatu konsep seperti menjelaskan fungsi setiap alat indera pada manusia; (2) Pemahaman penafsiran, seperti dapat menghubungkan bagian-bagian terdahulu dengan yang diketahui berikutnya, dapat menghubungkan beberapa bagian 
grafik dengan kejadian, atau dapat membedakan yang pokok dari yang bukan pokok; (3) Pemahaman ekstaporasi, seseorang dikatakan paham apabila mampu melihat dibalik yang tertulis atau dapat membuat ramalan tentang konsekuensi sesuatu atau dapat memperluas persepsinya dalam arti waktu, dimensi, kasus atau masalahnya. Berdasarkan pendapat mengenai indikator pemahaman konsep yang telah diuraikan, dapat disimpulkan bahwa siswa yang telah memahami suatu konsep diindikasikan dengan siswa dapat menjelaskan konsep-konsep menggunakan bahasa sendiri, siswa mampu membedakan contoh dan bukan contoh dari konsep, dan siswa dapat menyimpulkan suatu konsep tanpa ada gambaran atau simbol tertentu.

Pemahaman konsep merupakan bagian yang paling penting dalam pembelajaran IPA, karena dengan menguasai konsep dengan baik akan memudahkan siswa dalam mempelajari maupun mengerjakan soal-soal IPA. Untuk menanamkan suatu konsep dalam pelajaran, seorang guru perlu mengajarkannya dalam konteks nyata dengan mengaitkannya terhadap lingkungan sekitar. Hal ini akan mampu mengembangkan kemampuan berpikir kritis siswa dan meningkatkan pemahaman konsepnya terhadap materi yang diajarkan. Konsep-konsep yang ada dalam Pembelajaran IPA harus dapat dipahami dengan baik oleh siswa dalam pembelajaran. Hal ini dikarenakan siswa yang memiliki kemampuan pemahaman konsep yang tinggi akan mudah mengaplikasikan masalah Ilmu Pengetahuan Alam dalam kehidupan sehari-hari.

\section{Model Pembelajaran Inkuiri dengan Metode Gallery Walk dalam Mengoptimalkan Pemahaman Konsep Belajar IPA}

Proses optimalisasi pemahaman konsep belajar IPA pada siswa SD dapat dapat dilakukan dengan menggunakan model pembelajaran inkuiri. Model pembelajaran tersebut memberikan kebebasan kepada siswa untuk belajar sesuai dengan gaya belajar mereka sehingga memudahkan proses pembelajaran terutama pada proses pemahaman konsep. Pemahaman konsep belajar IPA siswa dapat terjadi secara optimal jika model pembelajaran inkuiri dipadukan dengan metode pembelajaran gallery walk. Metode pembelajaran gallery walk memberikan kesempatan bagi siswa bekerja sama antar siswa dalam kelompok kecil untuk menyampaikan materi yang ada ke kelompok lain sehingga siswa aktif bertanya, mempertanyakan, dan mengemukakan. Siswa berdiskusi, saling mengoreksi pemahaman dan berpresentasi, sehingga siswa terlibat aktif dalam aktivitas-aktivitas belajar di kelas. Selain itu, setiap kelompok melakukan presentasi, guru mengklarifikasi dan bersama-sama menyimpulkan agar tidak terjadi kesalahan dalam memahami konsep yang diperoleh. Model pembelajaran inkuiri dan metode pembelajaran gallery walk sama-sama memberikan kebebasan kepada siswa dalam belajar sesuai dengan gaya belajar mereka. Siswa dituntut untuk aktif dan berpikir kritis dalam memecahkan suatu permasalahan.

Pada tahapan melakukan survey mengenai hasil belajar terhadap kelompok lain dalam metode pembelajaran gallery walk dapat diterapkan dalam model pembelajaran inkuiri pada langkah melakukan observasi atau pengamatan. Pada tahap ini siswa mencari konsep-konsep yang tidak biasa untuk dipecahkan sesuai dengan kelompok masing-masing. Kemudian tiap-tiap kelompok menyampaikan kesimpulan dari apa yang mereka peroleh. Guru disini berperan sebagai fasilitator dan pembimbing siswa dalam proses pembelajaran. Hal ini akan membuat pembelajaran terasa lebih bermakna dan siswa dengan mudah memahami konsep belajar dengan baik. Model pembelajaran inkuiri dipadukan dengan metode pembelajaran gallery walk sangat memudahkan siswa dalam menemukan pengetahuan baru dan mempermudah daya ingat siswa jika proses penemuan itu dialami secara langsung. Pemahaman konsep belajar juga akan optimal dengan adanya integrasi antara model pembelajaran inkuiri dengan metode pembelajaran gallery walk.

\section{KESIMPULAN}

Kemampuan pemahaman konsep adalah kemampuan siswa berupa penguasaan materi pelajaran dimana siswa tidak hanya menghafal atau mengingat suatu konsep yang dipelajari tetapi mampu menyatakan ulang konsep tersebut dalam bentuk lain yang mudah dimengerti. Kemampuan 
pemahaman konsep ini merupakan bagian terpenting dalam pembelajaran IPA sebab dengan menguasai konsep materi dasar atau prasyarat akan memudahkan siswa dalam memahami dan memecahakan masalah dalam pembelajaran IPA. Konsep belajar adalah hal yang paling dasar dan paling pertama diajarkan oleh guru. Konsep belajar menjadi penentu hasil akhir dari proses pembelajaran. Tingkat keberhasilan siswa dalam menguasai pembelajaran tergantung pada sejauh mana siswa menguasi konsep belajar tersebut.

Pada proses optimalisasi pemahaman konsep belajar IPA diperlukan model dan metode pembelajaran yang tepat. Model dan metode pembelajaran menjadi satu diantara faktor penentu dalam keberhasilan pemahaman konsep belajar siswa. Adanya perpaduan antara model pembelajaran inkuiri dan metode pembelajaran gallery walk, diharapkan mampu mengoptimalkan proses pemahaman konsep belajar siswa. Hal tersebut karena model pembelajaran inkuiri dan metode pembelajaran gallery walk memfokuskan kegiatan pembelajaran yang berpusat kepada siswa. Siswa dituntut untuk berpikir kritis dalam memecahkan permasalahan yang ditemukan. Selain itu, siswa juga belajar sesuai dengan gaya belajar mereka sehingga memudahkan siswa dalam memahami konsep belajar IPA.

\section{DAFTAR PUSTAKA}

Anderson, L., dan Krathwohl, D. (2010). Kerangka Landasan untuk Pembelajaran, Pengajaran, dan Assesmen. Yogyakarta: Pustaka Belajar.

Buyung, B., \& Dwijanto, D. (2017). Analisis Kemampuan Literasi Matematis melalui Pembelajaran Inkuiri dengan Strategi Scaffolding. Unnes Journal of Mathematics Education Research, 6(1), 112-119.

Buyung, B., Nirawati, R., \& Kusumawati, I. (2016). Pengaruh Strategi Pembelajaran Inkuiri (SPI) Terhadap Kemampuan Pemahaman Konsep Siswa Kelas VIII SMP Negeri 18 Singkawang. JPMI (Jurnal Pendidikan Matematika Indonesia), 1(2), 87-90.

Dengo, F. (2018). Penerapan Metode Gallery Walk dalam Meningkatkan Hasil Belajar Peserta Didik pada Pembelajaran IPA. Jurnal Manajemen Pendidikan Islam, 6(1), 40-52.

Departemen Pendidikan Nasional (Depdiknas). (2003). Undang-Undang Republik Indonesia Nomor 20 Tahun 2003 Tentang Sistem Pendidikan Nasional. Jakarta: CV Mitra Karya.

Desi, D.R. (2010). Efektivitas Penerapan Strategi Pembelajaran Aktif Model Gallery of Learning Terhadap Partisipasi dan Prestasi Belajar IPA Biologi Pada Materi Sistem Pencernaan Makanan Siswa MTsN Sumberagung Jetis Bantul Yogyakarta. Skripsi. Yogyakarta: Fakultas Sains dan Teknologi UIN Sunan Kalijaga.

Indah, F. (2012). Model Pembelajaran Inkuiri. http://carapedia.com/ model_pembelajaran inkuiri_info612.html (diakses tanggal 26 Desember 2019).

Komalasari, K. (2011). Pembelajaran Kontekstual, Konsep dan Aplikasi. Bandung: Alfabeta.

Laura, E. dkk. (2014). Strategi Pembelajaran. Jakarta: Indeks.

Mariam, F.S.H. (2017). Pembelajaran Berbasis Proyek Metode Gallery Walk untuk Meningkatkan Hasil Belajar Siswa pada Materi Ekskresi Manusia. Jurnal Pendidikan Biologi, 4(2).

Purwanto, N. (2008). Prinsip-prinsip dan Teknik Evaluasi Pengajaran. Bandung: PT Remaja Rosdakarya.

Sagala, S. (2009). Konsep dan Makna Pembelajaran. Bandung: Alfabeta.

Samatowa, U. (2016). Pembelajaran IPA di Sekolah Dasar. Jakarta: PT Indeks.

Sanjaya, A. (2011). Pembelajaran Inkuiri. http://aadesanjaya.blogspot.com/2011/03/pembelajaraninquiry.html (diakses tanggal 26 Desember 2019).

Sanjaya, W. (2012). Strategi Pembelajaran Berorientasi Standar Proses Pendidikan. Jakarta: Prenamedia Group.

Silberman, M.L. (2006). Active Learning 101 Cara Belajar Siswa Aktif. Bandung: Nuansa Cendekia. p. 2745.

Sumarli, S. (2018). Analisis Model Pembelajaran Tipe Think-Pair-Share Berbasis Pemecahan Masalah Terhadap Keterampilan Berpikir Tingkat Tinggi Siswa. JIPF (Jurnal Ilmu Pendidikan Fisika), $3(1), 8-13$. 
Sumarli, S., Murdani, E., \& Wijaya, A. K. (2017). Pengembangan Buku Petunjuk Praktikum Fisika: Pengujian Jenis Kawat Konduktor Komersial. JIPF (Jurnal Ilmu Pendidikan Fisika), 2(2), 3034.

Susanto, A. (2016). Teori Belajar dan Pembelajaran di Sekolah Dasar. Jakarta: Prenadamedia Grup.

Tjandra dkk. (2005). Pendidikan Ilmu Pengetahuan Sosial Di Sekolah Dasar. Singaraja: Universitas Pendidikan Ganesha.

Trianto. (2009). Mendesain Model Pembelajaran Inovatif-Progresif. Jakarta: Kencana Prenada Media Group.

Uno dan Mohamad. (2014). Belajar dengan Pendekatan Pailkem. Jakarta: PT. Rosdakarya.

Wirdati, S. dkk. (2013). Pembelajaran Gallery Walk Berpendekatan Contextual Teaching Learning Materi Sistem Pencernaan di SMA. Journal of Biology Education, 2(1). 